\title{
Haploid Helps Phaeocystis Globosa Distribute to Deeper Dim Water, as Evidenced by Growth and Photosynthetic Physiological Responses to Different Irradiances
}

Junlian Zhuang

Guangxi University

Jiachang Lu

Guangxi Academy of Sciences

Kun-Fang Cao ( $\square$ kunfangcao@gxu.edu.cn )

Guangxi University https://orcid.org/0000-0002-2253-7189

Jie Li

Guangxi Academy of Sciences

\section{Research Article}

Keywords: Phaeocystis globosa, low irradiances, haploid cells, diploid cells, growth, physiological response

Posted Date: February 24th, 2022

DOI: https://doi.org/10.21203/rs.3.rs-1371588/v1

License: (9) This work is licensed under a Creative Commons Attribution 4.0 International License. Read Full License 


\section{Abstract}

Phaeocystis globosa has a haplo-diplontic alternative life cycle and is an important causative species of harmful algal blooms. We hypothesize that the haploid cells of Phaeocystis globosa could better adapt to deep dim water than its diploid cells. Haploid and diploid solitary cells of $P$. globosa were cultured with eutrophic medium ( $f / 2)$ under moderately low $\left(15 \mu\right.$ mol photons $\left.\mathrm{m}^{-2} \mathrm{~s}^{-1}\right)$, extremely low $(5 \mu \mathrm{mol}$ photons $\left.\mathrm{m}^{-2} \mathrm{~s}^{-1}\right)$ and normal $\left(60 \mu \mathrm{mol}\right.$ photons $\left.\mathrm{m}^{-2} \mathrm{~s}^{-1}\right)$ irradiance conditions. The results showed that irradiances used in this study did not induce reactive oxygen species (ROS) damage in either haploid or diploid cells. Both haploid and diploid solitary cells grew faster at higher irradiance during the exponential growth phase. However, the haploid abundances under moderately and extremely low irradiances were higher than that under normal irradiance after the exponential growth phase, but diploid cells formed more colonies at higher irradiances. An increase in the photosynthetic pigments (PSC) ratio combined with a reduction in photoprotective pigments (PPC) ratio were found in both ploidies with decreasing irradiance, but the ratios of PSC and PPC and xanthophyll cycle pigments were significantly higher in haploid cells than in diploid cells. For haploids, the highest potential photochemistry efficiency of photosystems $\Pi$ was found under extremely low irradiance, but for diploids, it was observed under moderately low irradiance. The results suggest that both haploid and diploid solitary cells of $P$. globosa in eutrophic water can survive under low-light conditions, but haploid cells have an advantage in extremely low irradiance.

\section{Introduction}

Phaeocystis, known for its massive bloom in the global ocean, is a cosmopolitan genus of phytoplankton belonging to Prymnwsiophyceae (Baumann et al. 1994; Peperzak 2000). Phaeocystis has drawn extensive public concern since it appears mainly in the form of visible colonies in surface water during blooms, which have caused serious ecological hazards and economic losses (Schoemann et al. 2005; Blauw et al. 2010; Wang et al. 2021). Harmful algal blooms caused by this genus have only been reported in 3 species, i.e., Phaeocystis globosa, Phaeocystis pouchetii and Phaeocystis antarctica. P. globosa is the most widespread species and produces blooms in both temperate and tropical coastal water (Rousseau et al. 1994; Peperzak and Gäbler-Schwarz 2012). This species is also an ecologically important algae in global carbon cycles because of its large carbon fixation during bloom formation, and it is also an important producer of dimethylsulfide (DMS), which connects sulfur cycling between the ocean and atmosphere (Rousseau et al. 1990; Arrigo et al. 1999; Smith et al. 2003; Hamm and Rousseau 2003).

Light is an important factor regulating the growth of phytoplankton (Falkowski and Raven 2007). Unlike the terrestrial ecosystem, light in water decreases with depth by several orders of magnitude because of light attenuation by water molecules and other absorbing materials (Dubinsky and Schofield 2010; Ramakrishnan 2018). Phytoplankton with specific vertical distributions have evolved a series of physiological mechanisms to adapt to this light variation. For example, Phaeocystis changed its chloroplast under low-light conditions by increasing the numbers of thylakoids (Moisan et al. 2006). In 
fact, most phytoplankton, including Phaeocystis, increase their light absorption capabilities under lowlight conditions by increasing the content of light-harvesting pigments combined with a reduction in photoprotective pigments (PPC) (Dubinsky and Stambler 2009; Pinchasov-Grinblat et al. 2011; Liu et al. 2011; Ramakrishnan 2018). In particular, Phaeocystis has relatively efficient xanthophyll cycling, i.e., interconversion between diadinoxanthin (dd) and diatoxanthin (dt), by which it can undergo a rapid response to variable light without extra energy costs for new pigment synthesis (Moisan et al. 1998; Meyer et al. 2000). In addition, the accumulation of reactive oxygen species (ROS) by phytoplankton is unavoidable during photosynthesis (Hajiboland 2014), which may cause irreversible damage to a cell (Fridovich 1998; Nishiyama et al. 2006; Falkowski and Raven 2007). In response to light stress, algal cells increase the activities of antioxidant enzymes for the removal of excess ROS (Asada 1999). Therefore, the specific irradiance range for phytoplankton survival is also dependent on its physiological capabilities.

Efficient photosynthesis and its phenotypic flexibility are considered pivotal factors for the dominance of Phaeocystis in phytoplankton communities (Cota et al. 1994). Field investigations have confirmed that Phaeocystis could survive from surface water to water at a depth of $300 \mathrm{~m}$, suggesting their extraordinary ability to cope well with both high- and low-irradiance environments (El-Sayed et al. 1983; Palmisano et al. 1986). Indeed, P. globosa, the most widespread marine Prymnwsiophyceae, has been documented to be able to grow in a wide range of irradiances from approximately 20 to $500 \mu \mathrm{mol}$ photons $\mathrm{m}^{-2} \mathrm{~s}^{-1}$ (Moisan and Mitchell 1999; Moisan et al. 2006; Xu et al. 2017; Liu et al. 2017; Wang et al. 2021). The nutrient levels in deep dim water are often high, and the species of phytoplankton in the sea acclimate to low-light conditions often have a deeper vertical distribution and more chances of using nutrients in the low-light layer (Dubinsky and Schofield 2010). However, the minimum irradiances used in their studies were mostly above $15 \mu \mathrm{mol}$ photons $\mathrm{m}^{-2} \mathrm{~s}^{-1}$, and knowledge about the response of $P$. globosa to lower irradiances, such as those in deep water, is still limited (Moisan and Mitchell 1999; Moisan et al. 2006; Liu et al. 2011; Xu et al. 2017; Wang et al. 2021).

P. globosa has an alternating life cycle of diploid and haploid phases (Vaulot et al. 1994; Dutz and Koski 2006; Peperzak and Gäbler-Schwarz 2012). Although the differences in extreme low-light adaptation between diploid and haploid $P$. globosa are still unknown, the different ecological strategies between diploid and haploid cells have been widely studied in other phytoplankton of Prymnwsiophyceae, for example, some species in the genus Coccolithophores. These studies have found that haploid cells are able to adapt to unfavorable environments such as low nutrients and irradiance (Green et al. 1996; Houdan et al. 2005; D'Amario et al. 2017; de Vries et al. 2021). Therefore, we hypothesize that the haploid of $P$. globosa has an advantage in extremely low-light environments and under low nutrient conditions over diploid cells. This paper presents the first study evaluating the low-light adaptation ability of different ploidy levels of $P$. globosa and will shed light on how the haplo-diplontic life cycle contributes to P. globosa success.

\section{Material And Methods}




\section{Strains and culture conditions}

P. globosa employed in this study was isolated from coastal water of the Beibu Gulf in southern China and supplied by the Culture Collection of Marine Algae, Guangxi Academy of Science. This strain was maintained in tubes with $\mathrm{f} / 2$ medium (-Si) under $60 \mu \mathrm{mol}$ photons $\mathrm{m}^{-2} \mathrm{~s}^{-1}$ irradiance with a $12 \mathrm{~h}: 12 \mathrm{~h}$ light/dark cycle. The salinity of the medium was $30 \mathrm{psu}$, and the culture temperature was $20^{\circ} \mathrm{C}$. Diploid cells of $P$. globosa can form colonies, but haploid cells cannot. During the culture of $P$. globosa, the cells that could not form colonies were identified as haploid cells ( $\mathrm{Li}$ et al. 2020). Previous studies have reported that some diploid strains sometimes turn into haploid solitary cells during culture instead of forming colonies (Janse et al. 1996; Mars Brisbin and Mitarai 2019; Li et al. 2020). A pure culture of haploid cells was obtained by isolating 1 haploid cell from a noncolony-forming tube with a micropipette, and spreading cultivation of haploid cells was conducted in the following experiments. To obtain a pure culture of diploid cells, 1 colony from the colony-forming tube was pipetted out and recultured in fresh medium. The diploid solitary cells used in the following experiments were obtained by filtering the colonies through a $10 \mu \mathrm{m}$ mesh via gravity. The abundance and ploidy of solitary cells were examined every day by flow cytometry (Beckman Coulter, Brea, California, USA) following the methods of Vaulot et al. (1994). The abundance of diploid cells in this study means that the abundance of diploid solitary cells and colonial cells was not included. The number of diploid solitary cells in the sample was counted after removal of colonies by gentle filtration via gravity using $10 \mu \mathrm{m}$ meshes. No interconversion between diploid and haploid solitary cells was found in the following experiments.

\section{Experimental design}

Culture experiments were performed to compare the low-light adaptation of diploid and haploid cells of $P$. globosa. First, diploid and haploid solitary cells were introduced into $20 \mathrm{I}$ glass carboys with an initial concentration of $0.22 \mu \mathrm{g} \mathrm{C} \mathrm{ml}^{-1}$, which was equal to a haploid cell abundance of $4.73 \times 10^{4} \mathrm{cells} \mathrm{ml}^{-1}$ or a

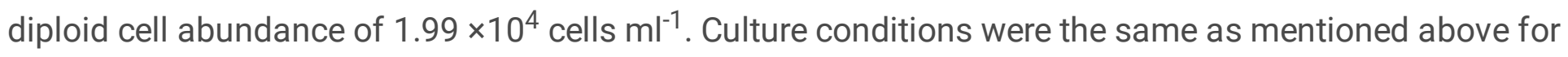
strain maintenance except for the light intensities, which were set as $5 \mu \mathrm{mol}$ photons $\mathrm{m}^{-2} \mathrm{~s}^{-1}, 15 \mu \mathrm{mol}$ photons $\mathrm{m}^{-2} \mathrm{~s}^{-1}$ and $60 \mu \mathrm{mol}$ photons $\mathrm{m}^{-2} \mathrm{~s}^{-1}$. The $5 \mu \mathrm{mol}$ photons $\mathrm{m}^{-2} \mathrm{~s}^{-1}$ irradiance level was shown to be approximately the lowest irradiance at which most phytoplankton can survive (Overmann and GarciaPichel 2006), $15 \mu \mathrm{mol}$ photons $\mathrm{m}^{-2} \mathrm{~s}^{-1}$ is the low irradiance used in most previous studies for the light adaptation of P. globosa (Moisan and Mitchell 1999; Moisan et al. 2006; Liu et al. 2011; Xu et al. 2017; Wang et al. 2021), and $60 \mu \mathrm{mol}$ photons $\mathrm{m}^{-2} \mathrm{~s}^{-1}$ is the irradiance known for maintaining optimum growth of $P$. globosa in the coastal water of the southern China Sea (Xu et al. 2017). Light was provided by cool white fluorescent tubes. Sampling was performed at approximately 10:00 am, samples for abundance analysis were taken every day, and samples for nutrients and the maximum quantum yield of photosystem II $\left(\mathrm{F}_{\mathrm{v}} / \mathrm{F}_{\mathrm{m}}\right)$ were taken every two days. Cell abundance was counted as mentioned above; nutrient concentrations and $F_{v} / F_{m}$ value during the culture experiment were measured as described below. Accompanied with this experiment, another triplicate cultivation (2.5 I) of diploid solitary cells using a conical flask was set for the colony count at the end of the experiment. 
An additional 20 I cultivation experiment with three repetitions was conducted to compare the differences in pigment compositions, antioxidative enzyme activities and malondialdehyde (MDA) content between haploid and diploid solitary cells of $P$. globosa. The initial abundance and culture conditions, including light intensities, were the same as those in the long-term culture experiments mentioned above. Samples for pigment analysis were taken at day 0 , day 3 and day 20, and samples for measurement of antioxidative enzyme activities and MDA content were taken at $0 \mathrm{~h}, 4 \mathrm{~h}, 8 \mathrm{~h}, 24 \mathrm{~h}, 48 \mathrm{~h}$, $96 \mathrm{~h}, 144 \mathrm{~h}$ and $192 \mathrm{~h}$. The details for pigment analysis and measurement of antioxidative enzyme activities and MDA content are described below.

\section{Measurement of $F_{v} / F_{m}$}

A water sample $(5 \mathrm{ml})$ was taken every day for $F_{v} / F_{m}$ measurement. It should be noted that colonies were gently removed before measuring the $F_{v} / F_{m}$ value of diploid solitary cells. The $F_{v} / F_{m}$ value was measured using a Phyto-PAM fluorometer (Heinz Walz GmbH, Effeltrich, Germany). The minimum $\left(F_{0}\right)$ and maximum fluorescence $\left(F_{m}\right)$ were recorded after 5 min of dark adaptation. $F_{v} / F_{m}$, the maximum quantum yield of PSII, was calculated as $\left(F_{m}-F_{0}\right) / F_{m}$.

\section{Nutrient analyses}

Samples $(25 \mathrm{ml})$ for nutrient determination were filtered through Whatman GF/F filters. The filtrate was kept at $-20^{\circ} \mathrm{C}$ until analysis. The concentrations of nitrate $\left(\mathrm{NO}_{3}{ }^{-}\right)$and phosphate $\left(\mathrm{PO}_{4}{ }^{3-}\right)$ were measured using a Skalar SANplus autoanalyzer, following the methods of Hansen and Koroleff (1999).

\section{Measurement of antioxidative enzyme activities and MDA content}

Algae samples $(200 \mathrm{ml})$ were collected by centrifuging cultivation mixtures at $12,000 \times \mathrm{g}$ for 15 min at $4{ }^{\circ} \mathrm{C}$ and then sonicating for $5 \mathrm{~min}$ after adding $1.5 \mathrm{ml}$ of phosphate buffer solution ( $\left.\mathrm{pH}=7.8\right)$. After sonication, the liquid was centrifuged, and the supernatant was kept at $-80^{\circ} \mathrm{C}$ until analysis. Superoxide dismutase (SOD) and catalase (CAT) activities were measured according to the method of Nounjan et al. (2012). MDA was extracted with $5 \%$ trichloroacetic acid $(\mathrm{w} / \mathrm{v})$, and its content was measured following the method thiobarbituric acid described by Heath and Packer (1968).

\section{HPLC pigment analysis}

Samples $(400 \mathrm{ml})$ for pigment analysis were filtered through Whatman GF/F filters (0.7 $\mu \mathrm{m})$, subsequently frozen in liquid nitrogen and then stored at $-80^{\circ} \mathrm{C}$ until analysis. Pigments were analyzed by an Agilent series 1100 HPLC equipped with a G1314A detector and Waters Symmetry C8 column ( $150 \mathrm{~mm} \times 4.6 \mathrm{~mm}, 3.5 \mu \mathrm{m}$ particle size, $100 \AA$ A pore size) according to the method of Zapata et al. (2000). Pigment peaks were identified based on absorbance spectra and retention times at $440 \mathrm{~nm}$, and retention times were compared with those of authentic standards obtained from DIH Inc. (Horsholm, Denmark), which included chlorophyll $a(\mathrm{Chl} a)$, chlorophyll $c 1$ (Chl c1), chlorophyll $c 2(\mathrm{Chl} c 2)$, chlorophyll c3 (Chl c3), pheophorbide a (Pheide a), pheophythin a (Phe a), Mg-2,4-divinylpheoporphyrin 
(Mg DVP), peridinin (Peri), fucoxanthin (Fuco), 19-but-fucoxanthin (But-Fuco), 19'-hex-fucoxanthin (HexFuco), prasinoxanthin (Pras), dd, dt and $\beta$-carotene ( $\beta$-Car). Pheide $a$, Phe $a$, and Pras were not detected; Mg DVP was not included because of the inability to replicate its separation. PPC were the sum of $d d, d t$ and $\beta$-Car; photosynthetic pigments (PSC) were the sum of chlorophyll $c$, Peri, Fuco and HexFuco. Pigment data were normalized to $\mathrm{Chl}$ a.

\section{Statistical analysis}

One-way ANOVA and least significant difference (LSD) tests for multiple comparisons were performed to evaluate the differences in antioxidative enzyme activities, MDA content and pigment compositions among different light treatments. The difference in colonial density between $\leq 100 \mu \mathrm{m}$ colonies and $>100$ $\mu \mathrm{m}$ colonies under the same irradiance treatments was assessed using a $t$-test. We did not conduct statistical analyses on culture experimental data due to the lack of replication. All of the analyses were performed using the statistical program SPSS 16.0, with a significance level of $5 \%$.

\section{Results}

\section{Abundance variations in haploid and diploid solitary cells}

Both haploid and diploid solitary cells grew more slowly with decreasing light intensity during the exponential growth phase. For haploid cells, the specific growth rate in the exponential phase was $0.18 \mathrm{~d}^{-1}, 0.29 \mathrm{~d}^{-1}$ and $0.32 \mathrm{~d}^{-1}$ at 5,15 and $60 \mu \mathrm{mol}$ photons $\mathrm{m}^{-2} \mathrm{~s}^{-1}$ treatments, respectively. Haploid abundance at $60 \mu \mathrm{mol}$ photons $\mathrm{m}^{-2} \mathrm{~s}^{-1}$ remained relatively stable after day 9 , with a mean value of $35.64 \times 10^{4}$ cells $\mathrm{ml}^{-1} \pm 6.41 \times 10^{4}$ cells $\mathrm{ml}^{-1}$ (Fig. $1 \mathrm{~A}$ ). The abundance of haploid cells under 5 and $15 \mu \mathrm{mol}$ photons $\mathrm{m}^{-2} \mathrm{~s}^{-1}$ irradiance continued to increase after day 9 and reached a higher level than that of cells cultured under an irradiance of $60 \mu \mathrm{mol}$ photons $\mathrm{m}^{-2} \mathrm{~s}^{-1}$. Although the abundance of haploids between the 5 and $15 \mu$ mol photons $\mathrm{m}^{-2} \mathrm{~s}^{-1}$ treatments was similar during the stable stage, the cell abundance at $15 \mu \mathrm{mol}$ photons $\mathrm{m}^{-2} \mathrm{~s}^{-1}$ reached the stable stage earlier than that at 5 $\mu \mathrm{mol}$ photons $\mathrm{m}^{-2} \mathrm{~s}^{-1}$. For diploid solitary cells, the specific growth rates during the exponential phase were $0.07 \mathrm{~d}^{-1}, 0.13 \mathrm{~d}^{-1}$ and $0.43 \mathrm{~d}^{-1}$ at 5,15 and $60 \mu \mathrm{mol}$ photons $\mathrm{m}^{-2} \mathrm{~s}^{-1}$, respectively. Unlike that of haploid cells, the abundance of diploid solitary cells fluctuated after early rapid growth, and no obvious differences were found among the different irradiance treatments after the rapid growth phase (Fig. 1 B). At the end of diploid culture experiments, no significant differences in the density of small colonies were found $(<100 \mu \mathrm{m})$ between the 5 and $15 \mu \mathrm{mol}$ photons $\mathrm{m}^{-2} \mathrm{~s}^{-1}$ treatments, but the density of total colonies and $>100 \mu \mathrm{m}$ colonies significantly increased with increasing irradiance $(p<0.05$, Fig. 2$)$. The colony size was significantly linearly correlated with the number of colonial cells under each irradiance condition. The regression slopes at 5 and $15 \mu \mathrm{mol}$ photons $\mathrm{m}^{-2} \mathrm{~s}^{-1}$ were similar but were approximately 1.7 times lower than that at $60 \mu \mathrm{mol}$ photons $\mathrm{m}^{-2} \mathrm{~s}^{-1}$, indicating denser colonial cells in mature colonies $(>250 \mu \mathrm{m})$ under the $60 \mu \mathrm{mol}$ photons $\mathrm{m}^{-2} \mathrm{~s}^{-1}$ treatment (Fig. 3). 


\section{Nutrient concentrations}

The concentrations of phosphate and nitrate at the start of the experiment were $36.19 \pm 0.85 \mu \mathrm{mol} \mathrm{I} \mathrm{I}^{-1}$ and $886.00 \pm 0.25 \mu \mathrm{mol} \mathrm{I}^{-1}$, respectively. The concentrations of phosphate and nitrate obviously decreased during the culture experiments, but the nutrient consumption by haploid cells was greater than that by diploid cells. At the end of the experiments, the phosphate concentration in the haploid group decreased to $20.56,12.14$ and $12.86 \mu \mathrm{mol} \mathrm{I}^{-1}$ under 5,15 and $60 \mu \mathrm{mol}$ photons $\mathrm{m}^{-2} \mathrm{~s}^{-1}$ irradiance, respectively, and the nitrate concentration in the haploid groups decreased to $676.50,527.24$ and 586.70 $\mu \mathrm{mol} \mathrm{I}^{-1}$ under 5,15 and $60 \mu \mathrm{mol}$ photons $\mathrm{m}^{-2} \mathrm{~s}^{-1}$ irradiance, respectively. However, the phosphate concentration in the diploid group decreased to $30.91,25.35$ and $20.31 \mu^{m o l ~ I}{ }^{-1}$ at the end of the experiment under irradiance treatments of 5,15 and $60 \mu \mathrm{mol}$ photons $\mathrm{m}^{-2} \mathrm{~s}^{-1}$, respectively, and the nitrate concentration in the diploid group decreased to $817.99,722.98$, and $655.09 \mu \mathrm{mol} \mathrm{I}^{-1}$ at the end of the experiment under irradiances of $5 \mathrm{~s}^{-1}, 15$ and $60 \mu \mathrm{mol}$ photons $\mathrm{m}^{-2} \mathrm{~s}^{-1}$, respectively (Fig. 4).

\section{$F_{v} / F_{m}$ value of haploid and diploid solitary cells}

The $F_{v} / F_{m}$ value of haploid cells ranged from 0.37 to 0.66 with a mean value of $0.54 \pm 0.08$, and that of diploid solitary cells ranged from 0.24 to 0.66 with a mean value of $0.53 \pm 0.11$. In haploid cells, the $F_{v} / F_{m}$ value decreased with increasing irradiances, indicating that haploid cells preferred an irradiance of 5 $\mu \mathrm{mol}$ photons $\mathrm{m}^{-2} \mathrm{~s}^{-1}$ over irradiances of 15 and $60 \mu \mathrm{mol}$ photons $\mathrm{m}^{-2} \mathrm{~s}^{-1}$. In contrast, the highest $\mathrm{F}_{\mathrm{v}} / \mathrm{F}_{\mathrm{m}}$ value in diploid appeared at an irradiance of $15 \mu \mathrm{mol}$ photons $\mathrm{m}^{-2} \mathrm{~s}^{-1}$. The $\mathrm{F}_{\mathrm{v}} / \mathrm{F}_{\mathrm{m}}$ value of diploid solitary cells in the $5 \mu \mathrm{mol}$ photons $\mathrm{m}^{-2} \mathrm{~s}^{-1}$ treatment was significantly decreased in comparison with those under the irradiances of 15 and $60 \mu \mathrm{mol}$ photons $\mathrm{m}^{-2} \mathrm{~s}^{-1}$, indicating the stress of the deficit of light energy under $5 \mu \mathrm{mol}$ photons $\mathrm{m}^{-2} \mathrm{~s}^{-1}$ for diploid solitary cells (Fig. 5).

\section{Antioxidant enzyme activities and MDA content}

The mean activities of CAT and SOD and MDA content in haploid cells were 1.41, 1.64 and 2.67 times higher than those in diploid solitary cells at the start of the experiment under irradiances of $5 \mathrm{~s}^{-1}, 15$ and $60 \mu \mathrm{mol}$ photons $\mathrm{m}^{-2} \mathrm{~s}^{-1}$, respectively (Fig. 6). The activities of CAT and SOD and the MDA content of haploid cells in all treatments decreased with the duration of the experiment and reached the lowest levels at the end of the experiment (192 h). However, the activities of CAT and SOD and the MDA content in the treatment of $5 \mu \mathrm{mol}$ photons $\mathrm{m}^{-2} \mathrm{~s}^{-1}$ were significantly higher $(\mathrm{p}<0.05)$ than under the other two irradiances after 48, 24 and $48 \mathrm{~h}$. Unlike haploid cells, the activities of CAT and SOD and the MDA content of diploid solitary cells remained relatively stable except for those in the $60 \mu \mathrm{mol}$ photons $\mathrm{m}^{-2} \mathrm{~s}^{-1}$ treatment after $8 \mathrm{~h}$. The activities of CAT and SOD and the MDA content of diploid solitary cells in the 60 $\mu \mathrm{mol}$ photons $\mathrm{m}^{-2} \mathrm{~s}^{-1}$ treatment increased from $8 \mathrm{~h}$ to the peak value at $24 \mathrm{~h}$ and then gradually decreased to approximately normal values at the end of the experiments (192 h), and the activities of CAT and SOD and the MDA content of diploid solitary cells during these processes were significantly higher in the $60 \mu \mathrm{mol}$ photons $\mathrm{m}^{-2} \mathrm{~s}^{-1}$ treatment than in the 5 and $15 \mu \mathrm{mol}$ photons $\mathrm{m}^{-2} \mathrm{~s}^{-1}$ treatments (Fig. 6). 


\section{Pigment composition}

The contents of pigments $d d, d t$ and the sum of $d d+d t$ were significantly higher in haploid cells than diploid solitary cells during the experiments $(p<0.05$ or $p<0.01$ ). The xanthophyll cycling pool (dd+dt) of haploid solitary cells was 1.72 2.18 times greater than that of diploid solitary cells of $P$. globosa. However, no significant differences were found among the different light treatments except for $\mathrm{dt}$ in haploid cells at day 20 and dd+dt in diploid solitary cells at day 3 (Fig. 7). Both PSC and PPC contents were significantly higher in haploid cells than diploid solitary cells during the experiment $(p<0.05$ or $\mathrm{p}<0.01$ ). The PSC content of haploid solitary cells was 2.20 2.46 times higher than that of diploid solitary cells of $P$. globosa during the experiment, and the PPC content of haploid solitary cells was 2.54 4.50 times higher than diploid solitary cells of $P$. globosa during the experiment. Moreover, the PSC content significantly increased with decreasing irradiance in both haploid and diploid solitary cells $(p<0.05)$, and in contrast, the PPC content significantly decreased with decreasing irradiance in both haploid and diploid solitary cells during experiments $(p<0.05$, Fig. 8$)$.

\section{Discussion}

\section{Growth and colony formation of P. globosa under low-light conditions}

Previous studies have reported that irradiances govern the growth and colony formation of Phaeocystis; generally, the growth rate of Phaeocystis cultured at light lower than saturating irradiance increases with light intensity (Peperzak 1993; Liu et al. 2011; Xu et al. 2017; Wang et al. 2021). The saturating irradiance of the $P$. globosa strain isolated from coastal water of southern China was $60 \mu \mathrm{mol}$ photons $\mathrm{m}^{-2} \mathrm{~s}^{-1}(\mathrm{Xu}$ et al. 2017). Consistent with previous studies, the growth of both diploid and haploid solitary cells increased with increasing irradiance ranging from 5 to $60 \mu \mathrm{mol}$ photons $\mathrm{m}^{-2} \mathrm{~s}^{-1}$ during the exponential phase (Fig. 1). However, the variation in the abundance of both diploid and haploid solitary cells after the exponential phase exhibited different patterns, and the highest abundance did not appear under an irradiance of $60 \mu \mathrm{mol}$ photons $\mathrm{m}^{-2} \mathrm{~s}^{-1}$ (Fig. 1).

The abundance of haploid cells after the exponential phase remained higher at 5 and $15 \mu \mathrm{mol}$ photons $\mathrm{m}^{-2} \mathrm{~s}^{-1}$ than at $60 \mu \mathrm{mol}$ photons $\mathrm{m}^{-2} \mathrm{~s}^{-1}$ (Fig. 1), indicating that haploid cells prefer relatively low light intensities in long-term cultivation. Although some species can survive at irradiances less than $2 \mu \mathrm{mol}$ photons $\mathrm{m}^{-2} \mathrm{~s}^{-1}$ (Raven and Cockell 2006), the minimum irradiance required by most phytoplankton is approximately $2 \mu \mathrm{mol}$ photons $\mathrm{m}^{-2} \mathrm{~s}^{-1}$ (Overmann and Garcia-Pichel 2006). The lowest irradiance used in this study was $5 \mu \mathrm{mol}$ photons $\mathrm{m}^{-2} \mathrm{~s}^{-1}$, close to the minimum irradiance need of most phytoplankton. Algae cope with low-light conditions through physiological adjustments, such as increasing the content of PSC to capture light, and this process is sensitive to nutrient supplies, especially the availability of nitrogen, phosphorus and iron (Garcia et al. 2009; Dubourg et al. 2015; Bender et al. 2018). The lowest concentrations of nitrogen and phosphorus were still higher than $500 \mu \mathrm{mol} \mathrm{I}^{-1}$ and $12 \mu \mathrm{mol} \mathrm{I}^{-1}$ at the end of the experiments (Fig. 4). It was reported that the growth of $P$. globosa was not inhibited at nitrogen and 
phosphorus concentrations higher than $1.7 \mu \mathrm{mol} \mathrm{I}^{-1}$ and $1 \mu \mathrm{mol} \mathrm{I} \mathrm{I}^{-1}$, respectively (Riegman and Boekel 1996; Xu et al. 2017). Although the iron concentration was not measured in this study, the iron concentration in our experiment was approximately $11.6 \mathrm{nmol} \mathrm{I}^{-1}$ at the start of the experiment according to the $\mathrm{f} / 2$ medium. A concentration of $0.2 \sim 0.4 \mathrm{nmol} \mathrm{I}^{-1}$ iron was shown to be sufficient to support Phaeocystis growth under low-light conditions (Sedwick et al. 2007; Garcia et al. 2009; Bender et al. 2018). Given that the $f / 2$ medium is eutrophic for algae growth and that algae assimilate micronutrients in a certain ratio with macronutrients (nitrogen and phosphorus), not only iron but also other nutrients were sufficient to support the growth of $P$. globosa in our experiments. The self-shading effect should also be considered in the research on the light effect, but haploids were more abundant under low-light conditions ( 2 and $5 \mu \mathrm{mol}$ photons $\mathrm{m}^{-2} \mathrm{~s}^{-1}$ ), which indicated that abundance variation did not contribute to self-shading effects. Haploid cells of $P$. globosa cultured at a relatively high but lower than saturating irradiance grew faster during short-term cultivation, but for long-term cultivation, haploid cells preferred lower light intensities. This is probably a result of long evolutionary adaptation rather than nutrient limitation or self-shading effects. Moreover, the $F_{v} / F_{m}$ value, a sensitive indicator of environmental stress (Sharma et al. 2015; Zha et al. 2017; Jamali Jaghdani et al. 2021), also confirmed the stress of 15 and 60 $\mu \mathrm{mol}$ photons $\mathrm{m}^{-2} \mathrm{~s}^{-1}$ on haploid cells (Fig. 5).

Unlike that of haploid cells, the abundance of diploid solitary cells fluctuated after the exponential phase, and abundance differences among different irradiance treatments were hard to identify (Fig. 1). This observation did not indicate a negligible effect of irradiances on diploid solitary cells because the $F_{v} / F_{m}$ value indicated that diploid solitary cells were clearly inhibited at 5 and $60 \mu \mathrm{mol}$ photons $\mathrm{m}^{-2} \mathrm{~s}^{-1}$ (Fig. 5). In contrast, no clear differences in diploid solitary cell abundance may be attributed to new colony formation from diploid solitary cells after several days of cultivation and the release of diploid solitary cells into water from the splitting of aged colonies (Rousseau et al. 1994, 2007). This process certainly caused fluctuations in the abundance of diploid solitary cells in water and masked the irradiance impact on the abundance. In fact, the effects of light intensities on diploid cells were found in more abundant colonies and denser colonial cells in mature colonies $(>250 \mu \mathrm{m})$ under higher irradiance treatments of 15 and $60 \mu \mathrm{mol}$ photons $\mathrm{m}^{-2} \mathrm{~s}^{-1}$ rather than under the extreme low-light conditions of $5 \mu \mathrm{mol}$ photons $\mathrm{m}^{-2}$ $\mathrm{s}^{-1}$ (Fig. 2 and Fig. 3), which, together with the $F_{v} / F_{m}$ value, indicated that diploid solitary cells could also survive under extreme low-light conditions $\left(5 \mu \mathrm{mol}\right.$ photons $\left.\mathrm{m}^{-2} \mathrm{~s}^{-1}\right)$, but photosynthesis and colony formation were inhibited under extremely low irradiances. Compared to haploid cells, diploid cells of $P$. globosa preferred higher irradiance, probably because colony formation required more carbon and energy supplies for the additional production of colonial membranes(Schoemann et al. 2005; Rousseau et al. 2007).

The bloom of $P$. globosa appears in the form of colonies. Irradiance is considered one of the most important triggers for the colony formation of $P$. globosa. It has been reported that when the light intensity is less than $100 \mathrm{~W} \mathrm{~h} \mathrm{~m}^{-2}$ (approximately $38 \mu \mathrm{mol}$ photons $\mathrm{m}^{-2} \mathrm{~s}^{-1}$ ) in a $12: 12 \mathrm{~h}$ light dark cycle, $P$. globosa appears mainly in the form of solitary cells (Peperzak 1993). Similar results were also reported 
by other researchers (Peperzak et al. 1998; Blauw et al. 2010), who found that $P$. globosa colonies occurred only when irradiance exceeded 25-35 $\mu \mathrm{mol}$ photons $\mathrm{m}^{-2} \mathrm{~s}^{-1}$. The $P$. globosa strain from Shantou coastal waters in southeastern China required higher irradiance for colony formation and failed to develop colonies when the irradiance was less than $50 \mu \mathrm{mol}$ photons $\mathrm{m}^{-2} \mathrm{~s}^{-1}$ (reviewed by Wang et al. 2021). However, colony formation was also observed at lower intensities of $10-20 \mu$ mol photons $\mathrm{m}^{-2} \mathrm{~s}^{-}$ 1 (Riegman and Boekel 1996). Diploid solitary cells in this study formed colonies in all irradiance treatments. It is likely that the irradiance threshold for colony formation is highly strain-dependent, and the strain used in this study coped well with relatively low irradiance levels. Nevertheless, the increase in colony density with light level has been widely reported in the studies mentioned above and was also confirmed by this study (Fig. 2). Interestingly, no ploidy transformation was found in our study, indicating that low irradiance was not a trigger for ploidy transformation of $P$. globosa, at least for this strain in a nutrient-sufficient system under a $12 \mathrm{~h}: 12 \mathrm{~h}$ light/dark cycle.

\section{Different physiological responses between haploid and diploid solitary cells under low-light conditions}

Acclimation to light involves an array of cellular responses, one of which is the pigment ratio, which is affected at extreme light levels (Ramakrishnan 2018). It has been repeatedly demonstrated in laboratory experiments and field observations that the main adjustment to low light by $P$. globosa and other phytoplankton is an increase in their light absorption capabilities by an increase in the content of lightharvesting pigments (PSC) and a reduction in PPC (Dubinsky and Stambler 2009; Pinchasov-Grinblat et al. 2011; Ramakrishnan 2018). Consistent with previous studies, the PSC content of both diploid and haploid solitary cells in the present study increased with declining irradiance, and PPC decreased with decreasing light intensity (Fig. 8). However, the PSC content of haploid cells was approximately two times higher than that of diploid solitary cells, indicating the advantage of haploid cells in coping with low-light conditions over diploid cells. Moreover, the PPC content of haploid cells was also significantly higher than diploid solitary cells, implying a wider tolerance range for irradiances in haploid cells. Consistent with our study, although ploidy was not examined in their study, Xu et al. (2017) suggested a wide irradiance tolerance range of flagellate cells, which were probably haploid cells based on their descriptions.

Xanthophyll cycling through interconversion between dd and dt has been observed in Phaeocystis (Moisan et al. 1998; Meyer et al. 2000). The conversion from dd to dt during the transition from low-light to relatively high-light conditions via a de-epoxidation reaction involves excess light energy dissipation leading to nondestructive thermal de-excitation of pigments (Olaizola et al. 1992; Brunet et al. 1993; Schubert et al. 1994; Meyer et al. 2000). The advantages of this mechanism are that it rapidly occurs in response to abrupt light change, lessens the cost of other pigment synthesis and does not affect the light harvesting efficiency (Brunet et al. 1993; Schubert et al. 1994). Therefore, the pigment pool associated with xanthophyll pigment cycling $(\mathrm{dd}+\mathrm{dt}$ ) has been used as an indirect measure of photoacclimation. Previous studies suggested that xanthophyll cycling in Phaeocystis was important for its bloom(Moisan and Mitchell 1999; Meyer et al. 2000). However, the differences in the xanthophyll pool between haploid and diploid solitary cells of $P$. globosa have not been reported. In this study, we demonstrated for the first time that the xanthophyll pool of haploid cells was approximately two times greater than that of diploid 
solitary cells (Fig. 7), implying that haploid cells not only cope well with extremely low irradiance conditions but also have competitive advantages in coping well with higher-light stress and responding to abrupt irradiance changes in comparison with diploid solitary cells. However, the effect of light intensity on conversion between $\mathrm{dd}$ and $\mathrm{dt}$ in both haploid and diploid solitary cells was not clearly observed in this study (Fig. 7) probably because the response of the xanthophyll cycle is rapid and often happens within several hours(Schubert et al. 1994; Moisan et al. 1998; Meyer et al. 2000), but the dd and dt contents in this study were examined only at day 0, day 3 and day 20 (Fig. 7).

The degree of ROS damage to phytoplankton could be indirectly measured by measuring antioxidant enzymes or peroxidation products, such as SOD activity, CAT activity and MDA content (Dat et al. 2000; Liu et al. 2017). For haploid cells, no significant increase in SOD activity, CAT activity or MDA content was found during experiments in all light treatments (Fig. 6), indirectly indicating that no ROS-induced damage was found in haploid cells even under the irradiance of $60 \mu \mathrm{mol}$ photons $\mathrm{m}^{-2} \mathrm{~s}^{-1}$ (Fig. 6). However, the activities of SOD and CAT and MDA content were higher at $0 \mathrm{~h}$ than at other sampling times under all irradiance treatments (Fig. 6), which is likely a normal physiological response when the cells were introduced to new culture conditions because the ROS contents of normal cells temporarily accumulate in response to abrupt environmental changes (Mittler 2002). Unlike haploid cells, diploid solitary cells were obtained by breaking colonies before introduction into new culture conditions. These colonies were originally cultured at $60 \mu \mathrm{mol}$ photons $\mathrm{m}^{-2} \mathrm{~s}^{-1}$, but the light actually acquired by colonial cells was lower than $60 \mu \mathrm{mol}$ photons $\mathrm{m}^{-2} \mathrm{~s}^{-1}$ because of the shading effects of the colonial membrane. Diploid solitary cells in $60 \mu \mathrm{mol}$ photons $\mathrm{m}^{-2} \mathrm{~s}^{-1}$ treatments suffered higher irradiance stress than others when they were introduced to new culture conditions. Therefore, the SOD and CAT activities and MDA content for diploid solitary cells significantly increased within $24 \mathrm{~h}$ only when they were cultured at 60 $\mu \mathrm{mol}$ photons $\mathrm{m}^{-2} \mathrm{~s}^{-1}$ but not in the lower irradiance treatments of 5 and $15 \mu \mathrm{mol}$ photons $\mathrm{m}^{-2} \mathrm{~s}^{-1}$. The SOD activity, CAT activity and MDA content of diploid solitary cells at $60 \mu \mathrm{mol}$ photons $\mathrm{m}^{-2} \mathrm{~s}^{-1}$ treatment gradually decreased to normal levels after $24 \mathrm{~h}$ (Fig. 6), indicating an absence of ROS damage to both haploid and diploid solitary cells.

\section{Ecological significance of different low-light responses in diploid and haploid solitary cells}

Both haploid and diploid solitary cells could survive in extreme low-light conditions in this study, but haploid cells exhibited more flexibility in response to light variations, which allowed for better performance of haploid cells in using light and nutrients in different layers of the water column. First, compared to diploid solitary cells, haploid cells preferred extreme low-light conditions in long-term cultivation. Nutrient levels are often high in the dim zone of the water column (Dubinsky and Schofield 2010). Haploid cells may sink to the dim layer and survive well for a long time when nutrients are depleted in surface water, for example, in summer. Second, haploid cells equipped with flagellates (Rousseau et al. 2007; Peperzak and Gäbler-Schwarz 2012) may swim to a specific water layer and stay there by flagellate movement, which allows for better utilization of solar energy and nutrients by haploid cells. The more efficient xanthophyll cycle and higher PPC content of haploid cells than of diploid solitary 
cells are helpful for vertical migration because they have to deal with the stress of frequent light variation and sometimes even photoinhibition. However, haploid cells are vulnerable to predators because they cannot form colonies, which is a useful strategy for defending against predators (Rousseau et al. 2007). Diploid cells require more solar energy because they need extra carbon for colony production (Schoemann et al. 2005) and the shading effects of gelatinous mucilage on colonial cells (diploid) once colony formation occurs. Therefore, diploid solitary cells may prefer higher irradiance conditions than haploid cells and are probably more suitable in the upper water layer. Overall, the diploid and haploid cells have different light utilization modes by which $P$. globosa might have a deeper vertical distribution and result in an increasing span of their ecological niches. However, the differences in the vertical distribution of haploid and diploid solitary cells in the water column should be clarified to make realistic projections in future studies.

\section{Conclusions}

To the best of our knowledge, this is the first study comparing the low light adaptation of different ploidy levels of $P$. globosa. We conclude that both haploid and diploid solitary cells of $P$. globosa in eutrophic water can survive under low-light conditions, but haploid cells have an advantage in extremely low irradiances. Haploid helps $P$. globosa distribute to deeper dim water and result in an increasing span of their ecological niches.

\section{Declarations}

\section{Acknowledgments}

We would like to thank thank Zhiming Zhao and Tian Xi for their help with culture.

\section{Authors' contributions}

K.F. Cao $\bigotimes J . C$. Lu and J.L. Zhuang conceived the ideas, designed the experiments, and wrote the manuscript. J.L. Zhuang carried out the experiments. All authors collected, analyzed the data and read, approved the final manuscript.

\section{Fundings}

This study was supported by the Guangxi Natural Science Foundation (No.2018GXNSFAA138194) and the Science and Technology Major Project of Guangxi (No.AA17202020).

\section{Availability of data and material}

The datasets generated and/or analysed during the current study are available from the corresponding author on a reasonable request.

\section{Conflict of interest}


The authors declare no conflict of interest.

\section{Ethical approval}

This article does not contain any studies conducted on human or animal subjects.

\section{References}

1. Arrigo KR, Robinson DH, Worthen DL, Dunbar RB, DiTullio GR, VanWoert M, Lizotte MP (1999) Phytoplankton community structure and the drawdown of nutrients and $\mathrm{CO}_{2}$ in the Southern Ocean. Science 283: 365-367. https://doi.org/10.1126/science.283.5400.365

2. Asada K (1999) The water-water cycle in chloroplasts: Scavenging of active oxygens and dissipation of excess photons. Annu Rev Plant Physiol Plant Mol Biol 50:601-639. https://doi.org/10.1146/annurev.arplant.50.1.601

3. Baumann MEM, Lancelot C, Brandini FP, Sakshaug E, John DM (1994) The taxonomic identity of the cosmopolitan prymnesiophyte Phaeocystis: a morphological and ecophysiological approach. J Marine Syst 5:5-22. https://doi.org/10.1016/0924-7963(94)90013-2

4. Bender SJ, Moran DM, Mcllvin MR, Zheng H, McCrow JP, Badger J, DiTullio GR, Allen AE, Saito MA (2018) Colony formation in Phaeocystis antarctica: connecting molecular mechanisms with iron biogeochemistry. Biogeosciences 15:4923-4942. https://doi.org/10.5194/bg-15-4923-2018

5. Blauw AN, Los FJ, Huisman J, Peperzak L (2010) Nuisance foam events and Phaeocystis globosa blooms in Dutch coastal waters analyzed with fuzzy logic. J Marine Syst 83:115-126. https://doi.org/10.1016/j.jmarsys.2010.05.003

6. Brunet C, Brylinski J, Lemoine Y (1993) In situ variations of the xanthophylls diatoxanthin and diadinoxanthin: photoadaptation and relationships with a hydrodynamical system in the eastern English Channel. Mar Ecol Pro Ser 102:69-77. https://doi.org/10.3354/meps102069

7. Cota GF, Smith WO, Mitchell BG (1994) Photosynthesis of Phaeocystis in the Greenland Sea. Limnol Oceanogr 39:948-953. https://doi.org/ 10.4319/lo.1994.39.4.0948

8. D’Amario B, Ziveri P, Grelaud M, Oviedo A, Kralj M (2017) Coccolithophore haploid and diploid distribution patterns in the Mediterranean Sea: can a haplo-diploid life cycle be advantageous under climate change? J Plankton Res 39:781-794. https://doi.org/10.1093/plankt/fbx044

9. Dat J, Vandenabeele S, Vranova E, Van Montagu M, Van Breusegem F (2000) Dual action of the active oxygen species during plant stress responses. Cell Mol Life Sci 57:779-795. https://doi.org/10.1007/s000180050041

10. De Vries J, Monteiro F, Wheeler G, Poulton A, Godrijan J, Cerino F, Malinverno E, Langer G, Brownlee C (2021) Haplo-diplontic life cycle expands coccolithophore niche. Biogeosciences 18:1161-1184. https://doi.org/10.5194/bg-18-1161-2021

11. Dubinsky Z, Schofield $O$ (2010) From the light to the darkness: thriving at the light extremes in the oceans. Hydrobiologia 639: 153-171. https://doi.org/10.1007/s10750-009-0026-0 
12. Dubinsky Z, Stambler N (2009) Photoacclimation processes in phytoplankton: mechanisms, consequences, and applications. Aquat Microb Ecol 56:163-176.

https://doi.org/10.3354/ame01345

13. Dubourg P, North RL, Hunter K, Vandergucht DM, Abirhire O, Silsbe GM, Guildford SJ, Hudson JJ (2015) Light and nutrient co-limitation of phytoplankton communities in a large reservoir: Lake Diefenbaker, Saskatchewan, Canada. J Great Lakes Res 41:129-143. https://doi.org/ 10.1016/j.jglr.2015.10.001

14. Dutz J, Koski M (2006) Trophic significance of solitary cells of the Prymnesiophyte Phaeocystis globosa depends on cell type. Limnol Oceanogr 51:1230-1238. https://doi.org/10.4319/lo.2006.51.3.1230

15. El-Sayed SZ, Biggs DC, Holm-Hansen O (1983) Phytoplankton standing crop, primary productivity, and near-surface nitrogenous nutrient fields in the Ross Sea, Antarctica. Deep-Sea Res Pt I 30:871886. https://doi.org/10.1016/0198-0149(83)90005-5

16. Falkowski PG, Raven JA (2007) Aquatic photosynthesis: Second Edition. Princeton University Press. https://doi.org/10.1515/9781400849727

17. Fridovich I (1998) Oxygen toxicity: a radical explanation. J Exp Biol 201:1203-1209. https://doi.org/10.1242/jeb.201.8.1203

18. Garcia N, Sedwick P, DiTullio G (2009) Influence of irradiance and iron on the growth of colonial Phaeocystis antarctica: implications for seasonal bloom dynamics in the Ross Sea, Antarctica. Aquat Microb Ecol 57:203-220. https://doi.org/10.3354/ame01334

19. Green JC, Course PA, Tarran GA (1996) The life-cycle of Emiliania huxleyi: A brief review and a study of relative ploidy levels analysed by flow cytometry. J Marine Syst 9:33-44. https://doi.org/ 10.1016/0924-7963(96)00014-0

20. Hajiboland R (2014) Reactive Oxygen Species and Photosynthesis. In: Oxidative Damage to Plants. Elsevier, pp 1-63. https://doi.org/10.1016/B978-0-12-799963-0.00001-0

21. Hamm CE, Rousseau V (2003) Composition, assimilation and degradation of Phaeocystis globosaderived fatty acids in the North Sea. J Sea Res 50:271-283. https://doi.org/10.1016/S13851101(03)00044-3

22. Hansen HP, Koroleff F (1999) Determination of nutrients, In: Grasshoff, K., Kremling, K., Ehrhardt, M. (Eds.), Methods of Seawater Analysis. 3rd edn Wiley-VCH, Weinheim, Germany, pp. 159-228. https://doi.org/10.1002/9783527613984.ch10

23. Heath RL, Packer L (1968) Photoperoxidation in isolated chloroplasts: I. Kinetics and stoichiometry of fatty acid peroxidation. Arch Biochem Biophys 125:189-198. https://doi.org/10.1016/00039861(68)90654-1

24. Houdan A, Probert I, Van Lenning K, Lefebvre S (2005) Comparison of photosynthetic responses in diploid and haploid life-cycle phases of Emiliania huxleyi (Prymnesiophyceae). Mar Ecol Prog Ser 292:139-146. https://doi.org/10.3354/meps292139 
25. Jamali Jaghdani S, Jahns P, Tränkner M (2021) Mg deficiency induces photo-oxidative stress primarily by limiting $\mathrm{CO}_{2}$ assimilation and not by limiting photosynthetic light utilization. Plant Science 302:110751. https://doi.org/10.1016/j.plantsci.2020.110751

26. Janse I, van Rijssel M, Gottschal J, Lancelot C, Gieskes W (1996) Carbohydrates in the North Sea during spring blooms of Phaeocystis: a specific fingerprint. Aquat Microb Ecol 10:97-103. https://doi.org/10.3354/ame010097

27. Li J, Lu J, Wang J, Wang Y, Lai J, Yu K (2020) Do diploid and haploid solitary cells of Phaeocystis globosa support the same copepod grazing, survival, egg production, and hatching success? J Coastal Res 37:113-121. https://doi.org/10.2112/JCOASTRES-D-20-00052.1

28. Liu S, Yu Z, Yao P, Zheng Y, Li D (2011) Effects of irradiance on pigment signatures of harmful algae during growth process. Acta Oceanol Sin 30:46-57. https://doi.org/10.1007/s13131-011-0160-1

29. Liu S, Yu Z, Song X, Cao X (2017) Effects of modified clay on the physiological and photosynthetic activities of Amphidinium carterae Hulburt. Harmful Algae 70:64-72. https://doi.org/10.1016/j.hal.2017.10.007

30. Mars Brisbin M, Mitarai S (2019) Differential gene expression supports a resource-intensive, defensive role for colony production in the bloom-forming haptophyte, Phaeocystis globosa. $\mathrm{J}$ Eukaryot Microbiol 66:788-801. https://doi.org/10.1111/jeu.12727

31. Meyer AA, Tackx M, Daro N (2000) Xanthophyll cycling in Phaeocystis globosa and Thalassiosira sp.: a possible mechanism for species succession. J Sea Res 43:373-384. https://doi.org/10.1016/S1385-1101(00)00031-9

32. Mittler R (2002) Oxidative stress, antioxidants and stress tolerance. Trends Plant Sci 7:405-410. https://doi.org/10.1016/S1360-1385(02)02312-9

33. Moisan T, Olaizola M, Mitchell B (1998) Xanthophyll cycling in Phaeocystis antarctica:changes in cellular fluorescence. Mar Ecol Prog Ser 169:113-121. https://doi.org/10.3354/meps169113

34. Moisan TA, Mitchell BG (1999) Photophysiological acclimation of Phaeocystis antarctica Karsten under light limitation. Limnol Oceanogr 44:247-258. https://doi.org/10.4319/lo.1999.44.2.0247

35. Moisan TA, Ellisman MH, Buitenhuys CW, Sosinsky GE (2006) Differences in chloroplast ultrastructure of Phaeocystis antarctica in low and high light. Mar Biol 149:1281-1290. https://doi.org/10.1007/s00227-006-0321-5

36. Nishiyama Y, Allakhverdiev SI, Murata N (2006) A new paradigm for the action of reactive oxygen species in the photoinhibition of photosystem II. BBA-Bioenergetics 1757:742-749. https://doi.org/10.1016/j.bbabio.2006.05.013

37. Nounjan N, Nghia PT, Theerakulpisut P (2012) Exogenous proline and trehalose promote recovery of rice seedlings from salt-stress and differentially modulate antioxidant enzymes and expression of related genes. J Plant Physiol 169:596-604. https://doi.org/10.1016/j.jplph.2012.01.004

38. Olaizola M, Bienfang PK, Ziemann DA (1992) Pigment analysis of phytoplankton during a subarctic spring bloom: xanthophyll cycling. J Exp Mar Biol Ecol 158:59-74. https://doi.org/10.1016/00220981(92)90308-W 
39. Overmann J, Garcia-Pichel F (2006) The phototrophic way of life. In: dworkin,m.(ed.) The prokaryotes: an evolving electronic resource for the microbiologica1community. Springer, New York

40. Palmisano AC, SooHoo JB, SooHoo SL, Kottmeier ST, Craft LL, Sullivan CW (1986) Photoadaptation in Phaeocystis pouchetii advected beneath annual sea ice in McMurdo Sound, Antarctica. J Plankton Res 8:891-906. https://doi.org/10.1093/plankt/8.5.891

41. Peperzak L (1993) Daily irradiance governs growth rate and colony formation of Emiliania huxleyi (Prymnesiophyceae). J Plankton Res 15:809-821. https://doi.org/10.1093/plankt/15.7.809

42. Peperzak L (2000) Observations of flagellates in colonies of Phaeocystis globosa (Prymnesiophyceae); a hypothesis for their position in the life cycle. J Plankton Res 22:2181-2203. https://doi.org/10.1093/plankt/22.12.2181

43. Peperzak L, Gäbler-Schwarz S (2012) Current knowledge of the life cycles of Phaeocystis globosa and Phaeocystis antarctica (prymnesiophyceae)1: phaeocystis life cycle. J Phycol 48:514517. https://doi.org/10.1111/j.1529-8817.2012.01136.x

44. Peperzak L, Colijn F, Gieskes WWC, Peeters JCH (1998) Development of the diatom- Phaeocystis spring bloom in the Dutch coastal zone of the North Sea: the silicon depletion versus the daily irradiance threshold hypothesis. J Plankton Res 20:517-537. https://doi.org/10.1093/plankt/20.3.517

45. Pinchasov-Grinblat $Y$, Hoffman R, Dubinsky Z (2011) The effect of photoacclimation on photosynthetic energy storage efficiency, determined by photoacoustics. Open J Mar Sci.1 1:43-49. https://doi.org/10.4236/ojms.2011.12005

46. Ramakrishnan R (2018) Low light phytoplankton genera observed in the coastal and estuarine waters of Goa, India. Appl Ecol Env Res 16:1783-1796. https://doi.org/10.15666/aeer/1602_17831796

47. Raven JA, Cockell CS (2006) Influence on photosynthesis of starlight, moonlight, planetlight, and light pollution (reflections on photosynthetically active radiation in the universe). Astrobiology 6:668-675. https://doi.org/10.1089/ast.2006.6.668

48. Riegman R, Boekel WV (1996) The ecophysiology of Phaeocystis globosa: A review. Netherlands J Sea Res 35:235-242. https://doi.org/10.1016/S1385-1101(96)90750-9

49. Rousseau V, Mathot S, Lancelot C (1990) Calculating carbon biomass of Phaeocystis sp. from microscopic observations. Mar Biol 107:305-314. https://doi.org/10.1007/BF01319830

50. Rousseau V, Vaulot D, Casotti R, Cariou V, Lenz J, Gunkel J, Baumann M (1994) The life cycle of Phaeocystis (Prymnesiophyceae): evidence and hypotheses. J Marine Syst 5:23-39. https://doi.org/10.1016/0924-7963(94)90014-0

51. Rousseau V, Chrétiennot-Dinet M-J, Jacobsen A, Verity P, Whipple S (2007) The life cycle of Phaeocystis: state of knowledge and presumptive role in ecology. Biogeochemistry 83:29-47. https://doi.org/10.1007/978-1-4020-6214-8_4

52. Schoemann V, Becquevort S, Stefels J, Rousseau V, Lancelot C (2005) Phaeocystis blooms in the global ocean and their controlling mechanisms: a review. J Sea Res 53:43-66. 
https://doi.org/10.1016/j.seares.2004.01.008

53. Schubert H, Kroon BM, Matthijs HC (1994) In vivo manipulation of the xanthophyll cycle and the role of zeaxanthin in the protection against photodamage in the green alga Chlorella pyrenoidosa. J Biol Chem 269:7267-7272. https://doi.org/10.1016/S0021-9258(17)37278-2

54. Sedwick P, Garcia N, Riseman S, Marsay C, DiTullio G (2007) Evidence for high iron requirements of colonial Phaeocystis antarctica at low irradiance. In: Phaeocystis, major link in the biogeochemical cycling of climate-relevant elements. Springer, pp 83-97. https://doi.org/10.1007/978-1-4020-62148_8

55. Sharma DK, Andersen SB, Ottosen C-O, Rosenqvist E (2015) Wheat cultivars selected for high $F_{v} / F_{m}$ under heat stress maintain high photosynthesis, total chlorophyll, stomatal conductance, transpiration and dry matter. Physiol Plantarum 153:284-298. https://doi.org/10.1111/ppl.12245

56. Smith WO, Dennett MR, Mathot S, Caron DA (2003) The temporal dynamics of the flagellated and colonial stages of Phaeocystis antarctica in the Ross Sea. Deep-Sea Res Pt II 50:605-617. https://doi.org/10.1016/S0967-0645(02)00586-6

57. Vaulot D, Birrien J-L, Marie D, Casotti R, Veldhuis MJ, Kraay GW, Chrétiennot-Dinet M-J (1994) Morphology, ploidy, pigment composition, and genome size of cultured strains of phaeocystis (prymnesiophyceae) 1. J Phycol 30:1022-1035. https://doi.org/10.1111/j.00223646.1994.01022.x

58. Wang J-X, Kong F-Z, Geng H-X, Zhao Y, Guan W-B, He C, Kang Z-J, Guo W, Zhou Z-X, Zhang Q-C, Yu R$C$ (2021) Pigment characterization of the giant colony-forming haptophyte Phaeocystis globosa in the Beibu Gulf reveals blooms of different origins. Appl Environ Microbiol AEM.01654-21. https://doi.org/10.1128/AEM.01654-21

59. Xu N, Huang B, Hu Z, Tang Y, Duan S, Zhang C (2017) Effects of temperature, salinity, and irradiance on the growth of harmful algal bloom species Phaeocystis globosa Scherffel (Prymnesiophyceae) isolated from the South China Sea. Chin J Ocean Limnol 35:557-565. https://doi.org/10.1007/s00343-017-5352-x

60. Zapata M, Rodríguez F, Garrido J (2000) Separation of chlorophylls and carotenoids from marine phytoplankton:a new HPLC method using a reversed phase $\mathrm{C} 8$ column and pyridine-containing mobile phases. Mar Ecol Prog Ser 195:29-45. https://doi.org/10.3354/meps195029

61. Zha T-S, Wu YJ, Jia X, Zhang MY, Bai YJ, Liu P, Ma JY, Bourque CP-A, Peltola H (2017) Diurnal response of effective quantum yield of PSIl photochemistry to irradiance as an indicator of photosynthetic acclimation to stressed environments revealed in a xerophytic species. Ecol Indic 74:191-197. https://doi.org/10.1016/j.ecolind.2016.11.027

\section{Figures}


Haploid

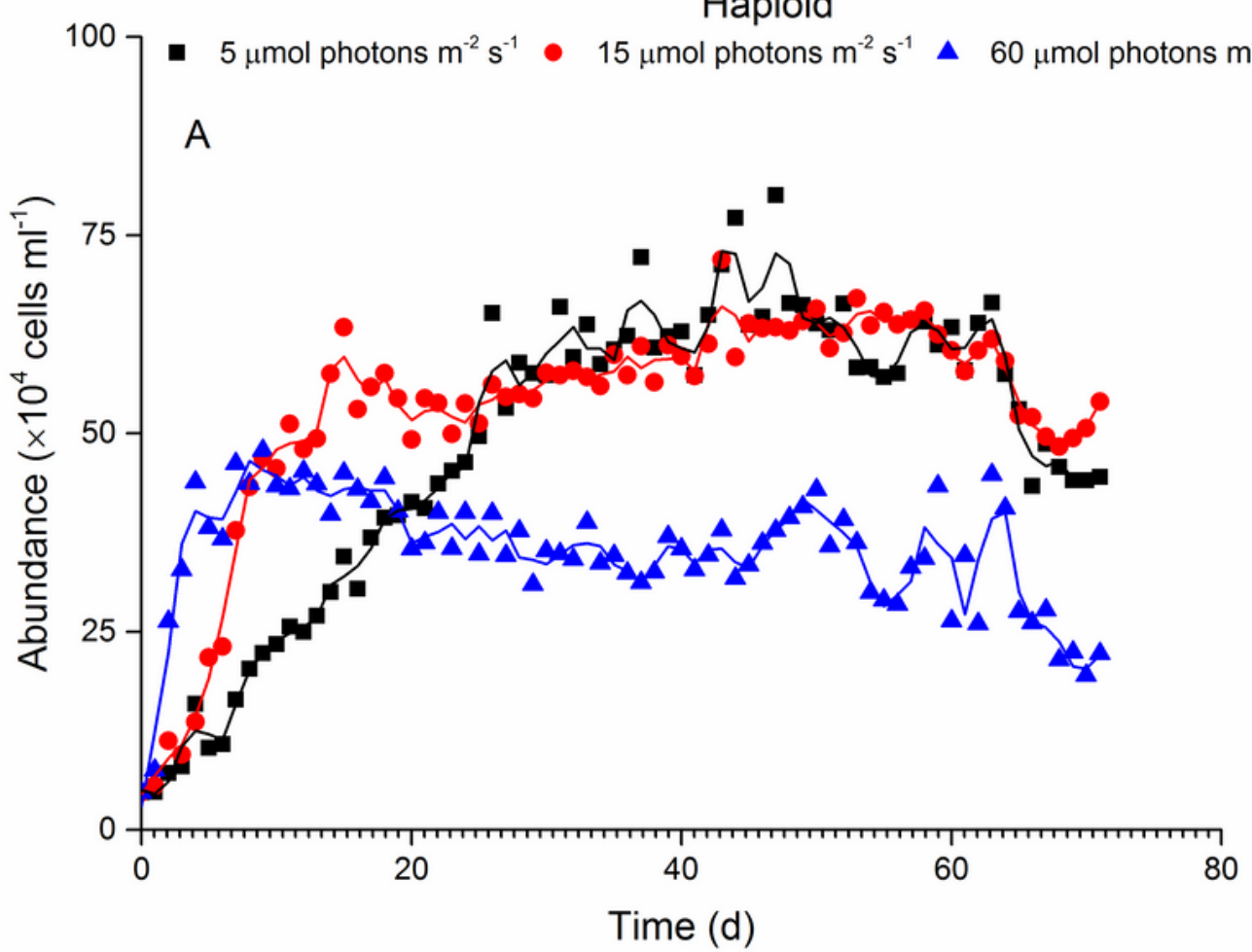

Diploid

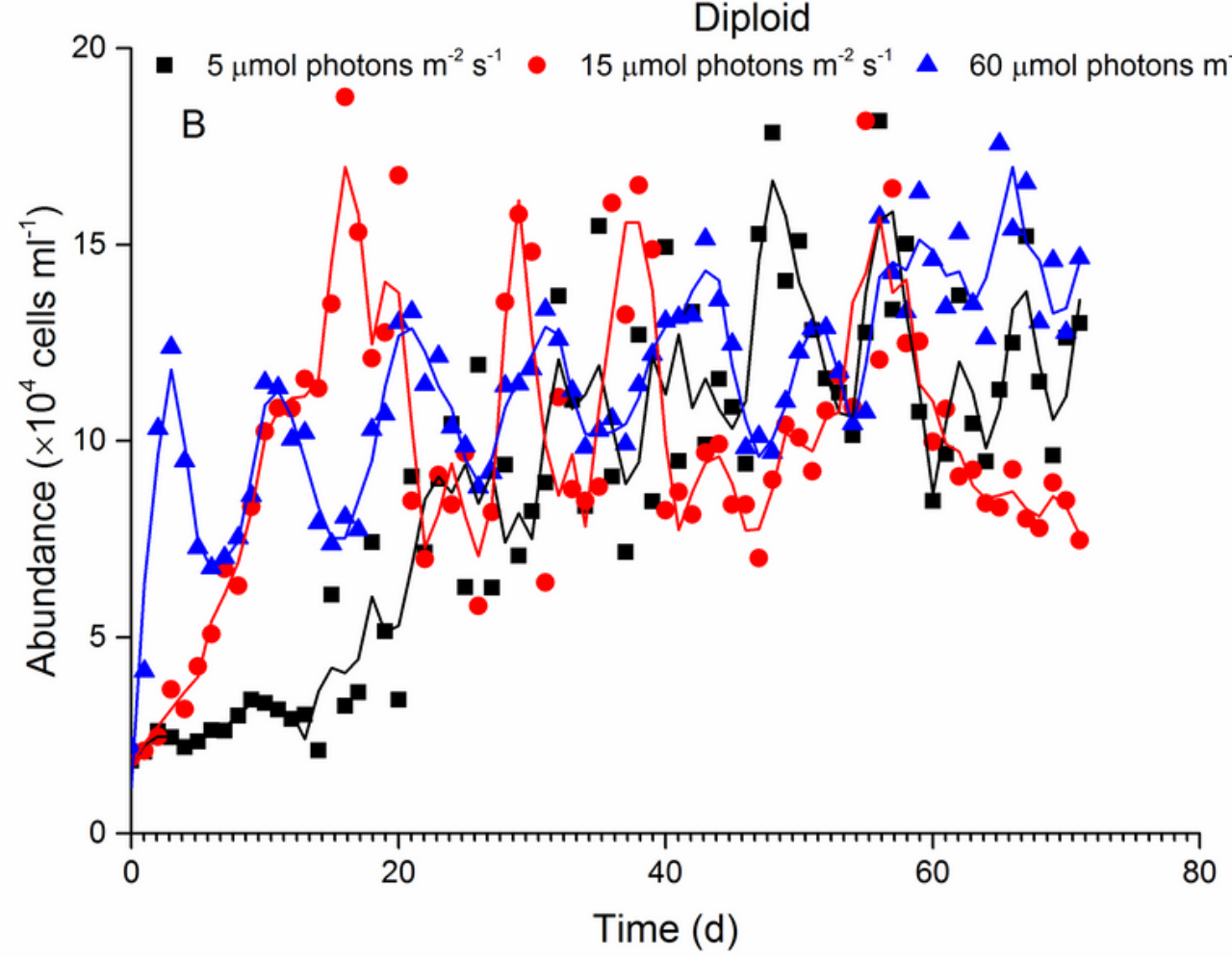

Figure 1

Variation in the abundance of haploid and diploid solitary cells of $P$. globosa under different low-light intensities 


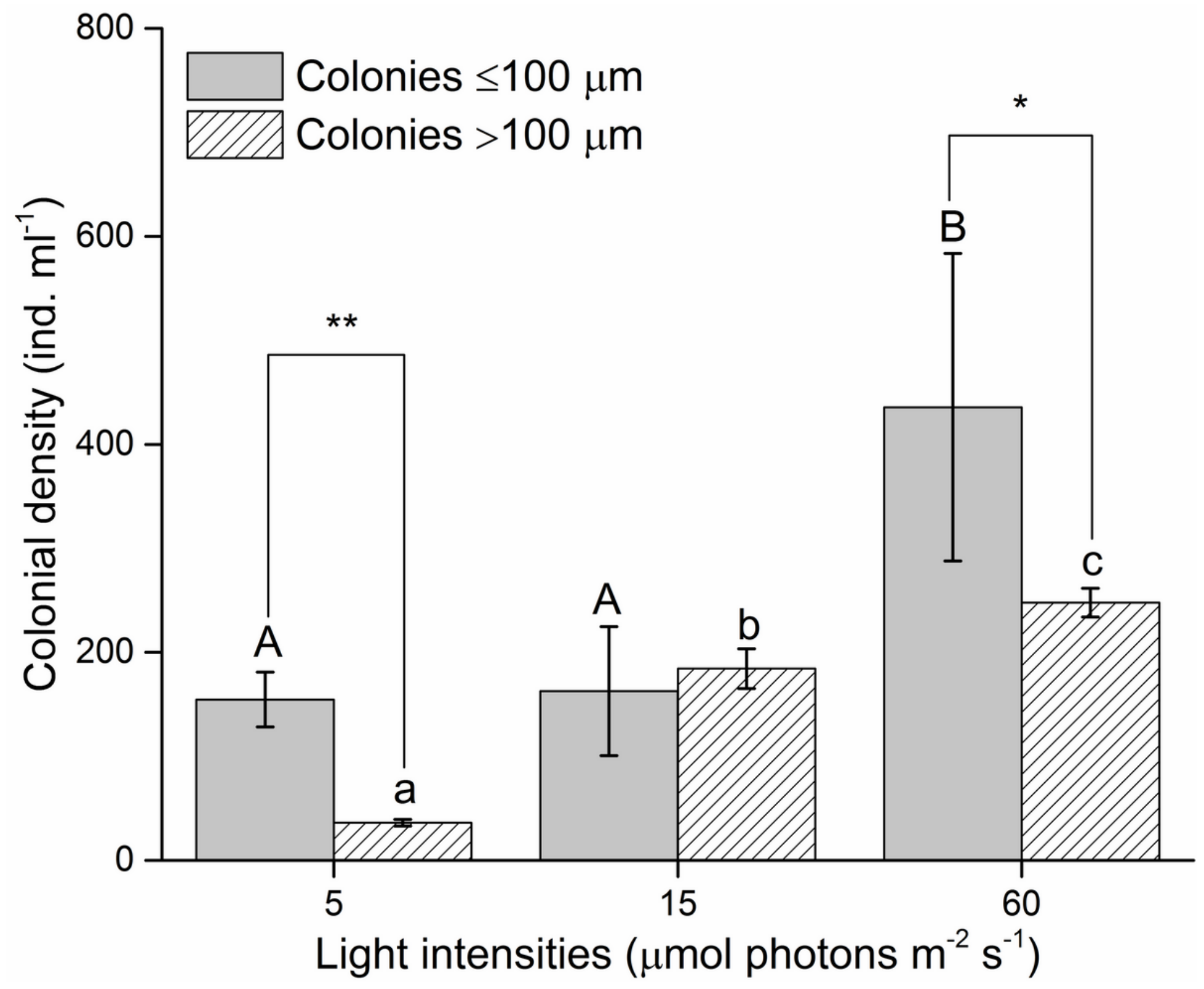

Figure 2

Colonial density under different light intensities at the end of diploid cell culture experiments. * and $* *$, significant difference $(p<0.05$ and $p<0.01)$ between the density of $\leq 100 \mu \mathrm{m}$ and $>100 \mu \mathrm{m}$ colonies in the same light intensities. Different uppercase and lowercase letters indicate significant differences among the three light intensities for $\leq 100 \mu \mathrm{m}$ and $>100 \mu \mathrm{m}$ colonies, respectively 


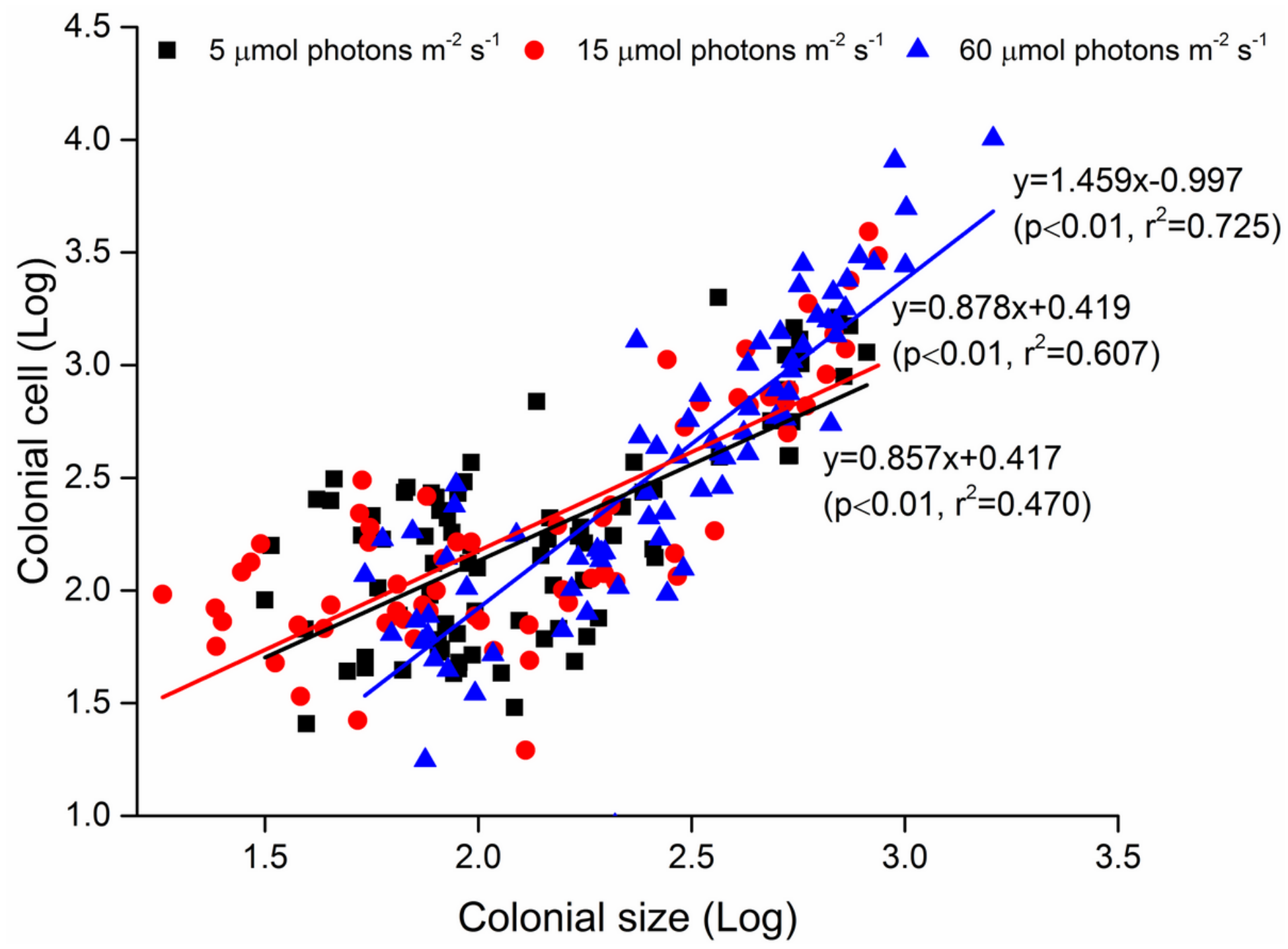

Figure 3

Relationships between colony size (log) and the number of colonial cells per colony (log). Data were obtained at the end of diploid culture experiments 
Haploid

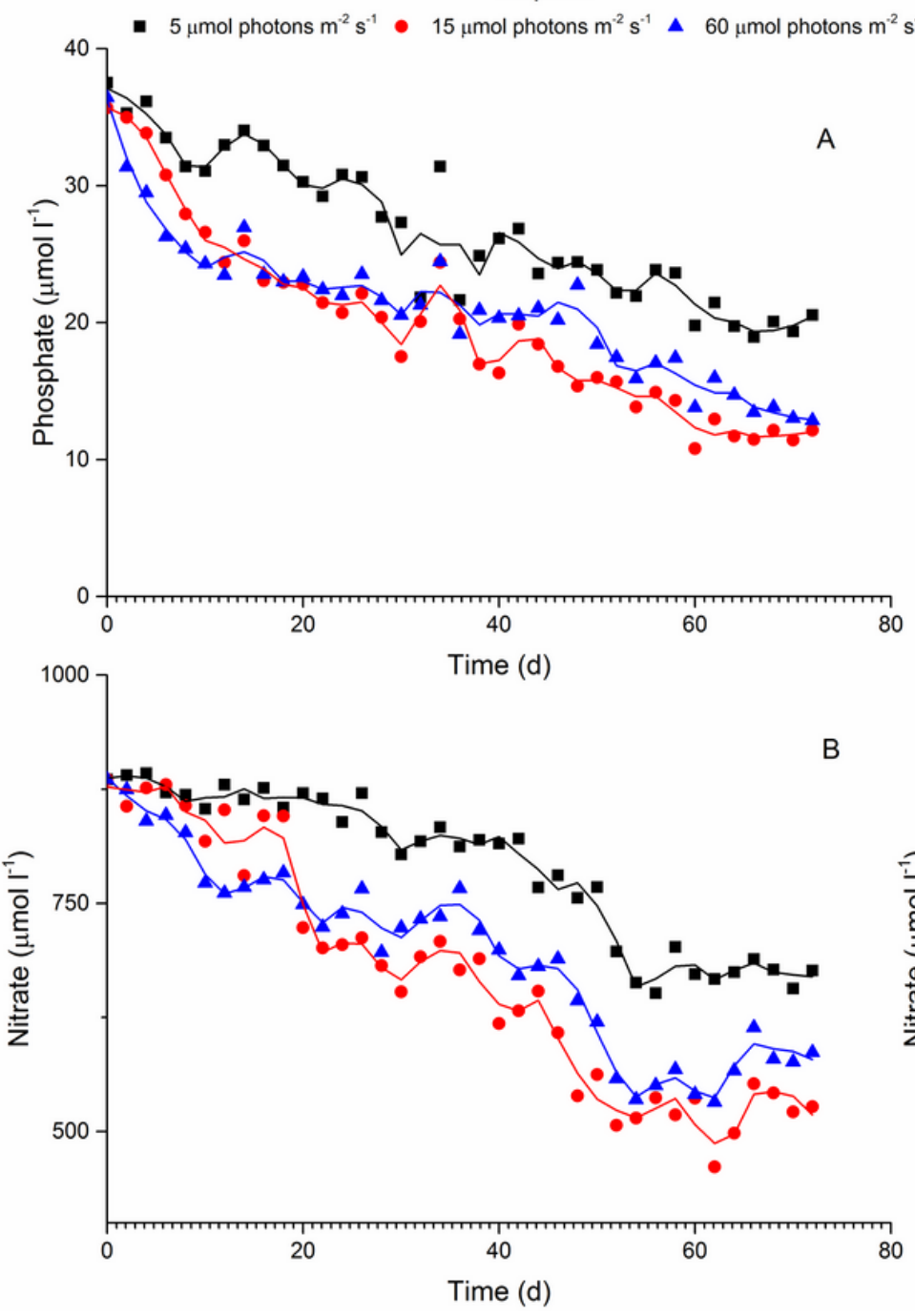

Diploid
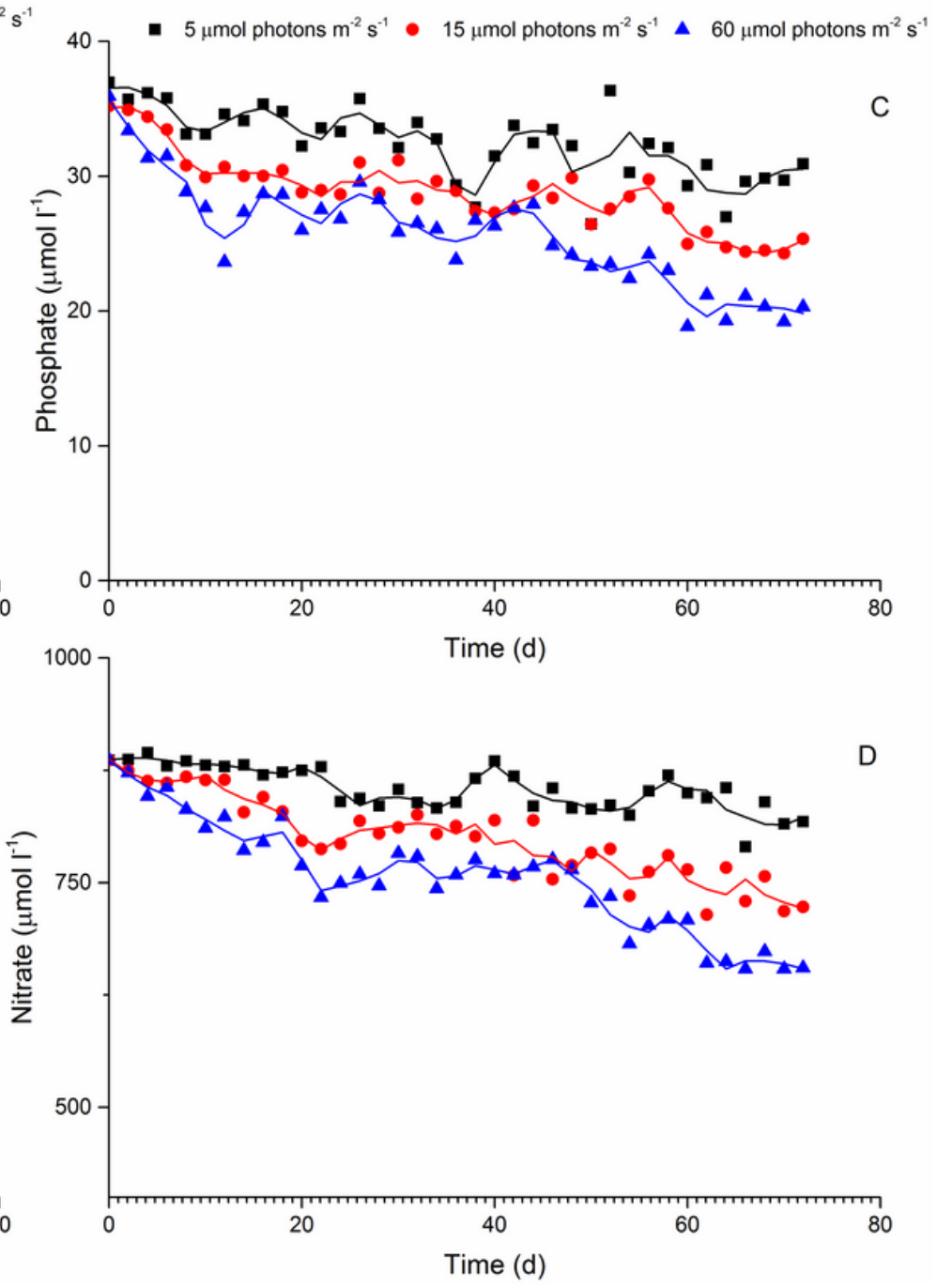

Figure 4

Variations in phosphate and nitrate concentrations in the culture of haploid and diploid cells of $P$. globosa under different light intensities. A and B, phosphate and nitrate concentrations in haploid cultures; $C$ and D, phosphate and nitrate concentrations in diploid cultures 

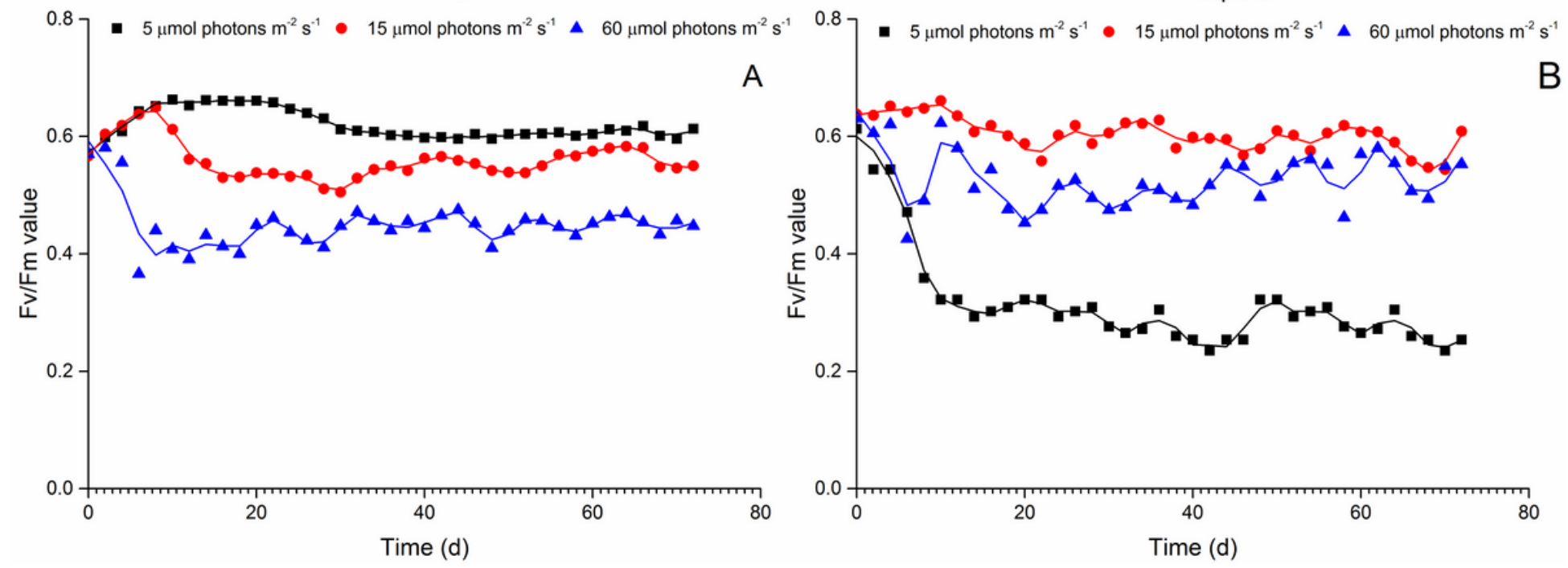

Figure 5

Variations in the maximum PSIl quantum yield (Fv/Fm) of haploid (A) and diploid solitary cells (B) of $P$. globosa under different light intensities

Haploid
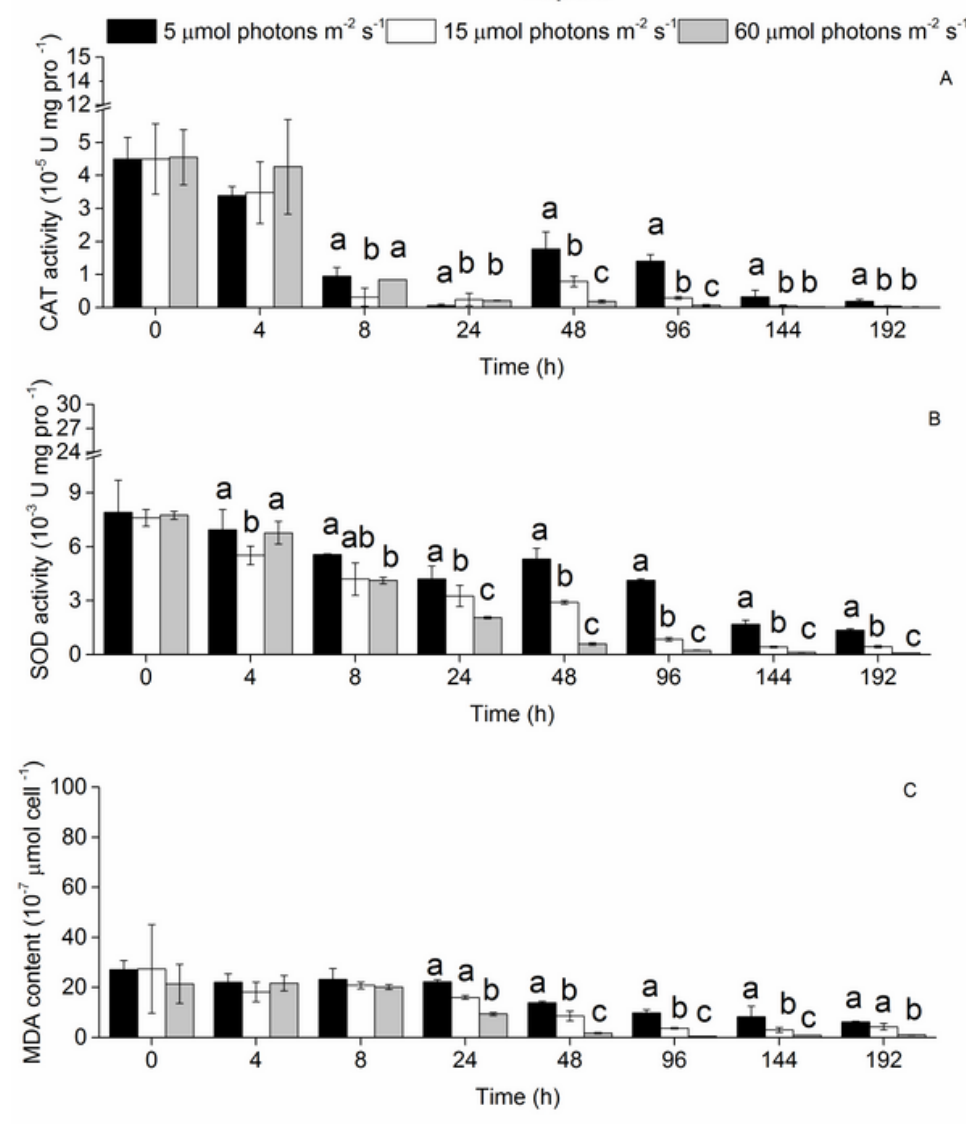

Diploid
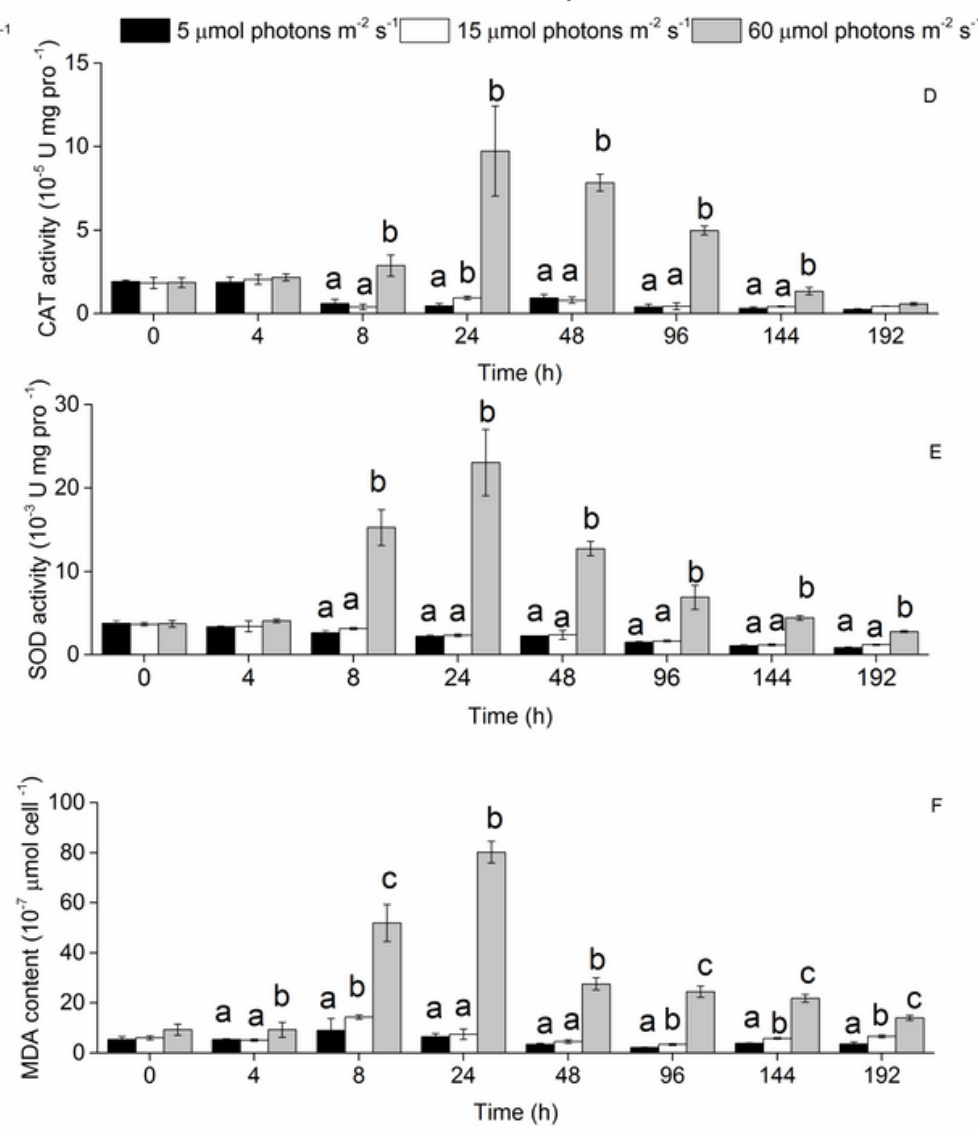

Figure 6 
CAT and SOD activities and MDA content in haploid and diploid solitary cells of $P$. globosa at $0 \mathrm{~h}, 4 \mathrm{~h}, 8 \mathrm{~h}$, 24 h, 48 h, 96 h, $144 \mathrm{~h}$ and $192 \mathrm{~h}$ under different irradiance treatments. Different lowercase letters indicate significant differences among the three light intensities at the same time. $A, B$ and $C$ for haploid cells; D, E and $\mathrm{F}$ for diploid solitary cells

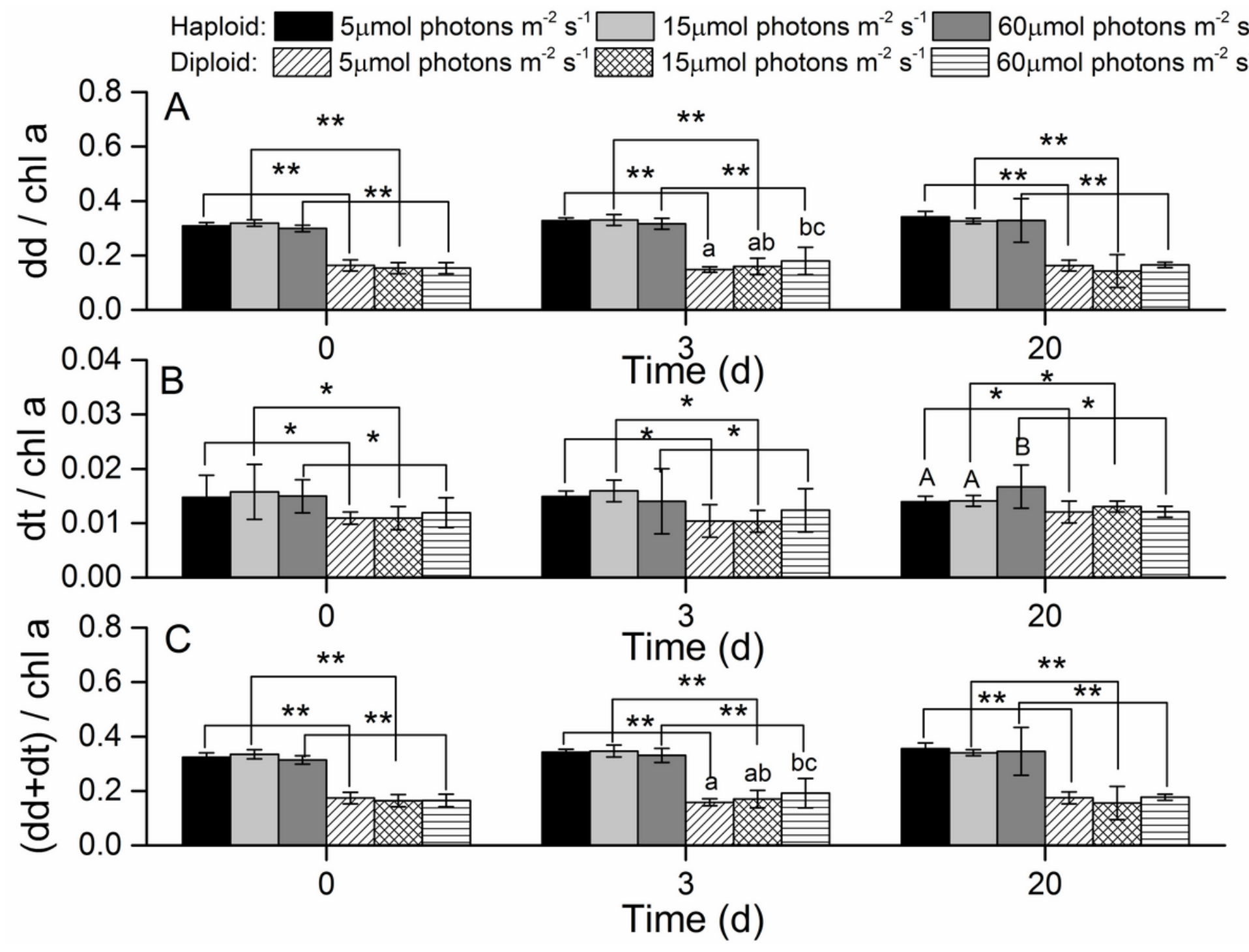

Figure 7

Average contents of diadinoxanthin (dd, A), diatoxanthin (dt, B) and sum of $d d$ and $d t(C)$ for haploid and diploid solitary cells of $P$. globosa under different light intensities at day 0 , day 3 and day 20. Data are normalized to the Chl a content. $*$ and ${ }_{* *}$ indicate significant differences $(p<0.05$ and $p<0.01)$ between haploid and diploid solitary cells on the same day. Different uppercase and lowercase letters indicate significant differences among the three light intensities for haploid and diploid solitary cells, respectively 


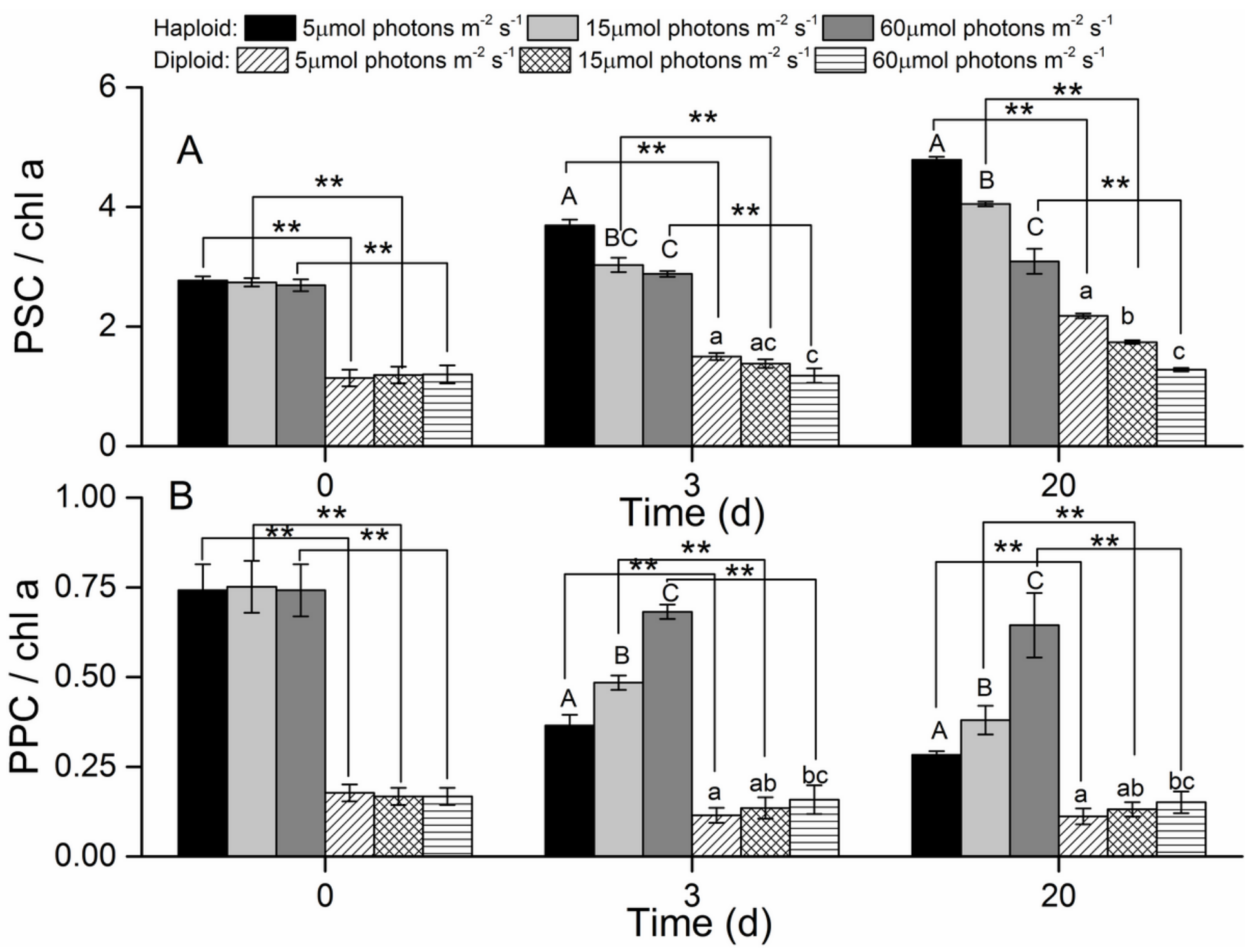

Figure 8

Averages of photosynthetic pigment (PSC, A) and photoprotective pigment (PPC, B) contents for haploid and diploid solitary cells of $P$. globosa under different light intensities at day 0 , day 3 and day 20. Data are normalized to the $\mathrm{Chl}$ a content. $*$ indicates a significant difference $(\mathrm{p}<0.01)$ between haploid and diploid solitary cells on the same day. Different uppercase and lowercase letters indicate significant differences among the three light intensities for haploid and diploid solitary cells, respectively 